\title{
Cotyledonoid Dissecting Leiomyoma with Symplastic Features: Case Report
}

\section{Leiomioma dissecante cotiledonoide com aspectos simplásticos: relato de caso}

\author{
Fatma Cavide Sonmez ${ }^{1}$ Zeynep Tosuner ${ }^{1}$ Ayse Filiz Gökmen Karasu ${ }^{2}$ Dilek Sema Arıcı ${ }^{1}$ \\ Ramazan Dansuk ${ }^{2}$ \\ ${ }^{1}$ Department of Pathology, School of Medicine, Bezmialem Vakif \\ University, Istanbul, Turkey \\ 2 Department of Gynecology and Obstetrics, School of Medicine, \\ Bezmialem Vakif University, Istanbul, Turkey

\begin{abstract}
Address for correspondence Ayse Filiz Gokmen Karasu, MD, Department of Gynecology and Obstetrics, Bezmialem Vakif University, Faculty of Medicine, Istanbul, Turkey (e-mail: afgokmen@gmail.com).
\end{abstract}

Rev Bras Ginecol Obstet 2017;39:436-440.

\begin{abstract}
Purpose Cotyledonoid dissecting leiomyoma is a leiomyoma variant exhibiting unusual growth patterns. We aimed to demonstrate this, as well as to point out another feature that has not been previously reported.

Case Report A congested, multinodular myomectomy specimen was resected. Histologically, smooth muscle fascicles with marked vascularity and extensive hydropic degeneration were detected. A total of 2 mitoses per 10 high power fields were counted, and the $\mathrm{K}_{\mathrm{i}}-67$ index was of $2-3 \%$. We encountered atypical bizarre cells that have not been previously reported. Coagulative necrosis was not present. The patient was alive and well 36 months after surgery, with no evidence of recurrence.

\section{Keywords}

- benign

- cotyledonoid

- leiomyoma

- symplastic

\section{Resumo} Conclusions Albeit the gross aggressive appearance, cotyledonoid dissecting leiomyomas are benign in nature. To this day, atypical cells have not been reported in this type of tumor. Despite the presence of symplastic features, cotyledonoid dissecting leiomyomas are clinically benign entities. Surgeons and pathologists should be acquainted with this variant.

Introdução O leiomioma dissecante na forma cotiledonoide é uma variante de leiomioma com padrões raros de crescimento. Além de demonstrá-los, vamos apontar outro aspecto anteriormente não relatado.

Relato de Caso Uma amostra congestionada, multinodular de miomectomia foi excisada. Histologicamente, detectaram-se fascículos de músculos lisos com marcada vascularidade e extensa degeneração hidrópica. Contaram-se 2 mitoses por 10 campos de alta potência, e o índice $\mathrm{K}_{\mathrm{i}}-67$ foi de 2-3\%. Encontramos células atípicas, bizarras, que não haviam sido relatadas anteriormente. Não foi observada necrose coagulativa. A paciente encontrava-se saudável e sem evidências de recorrência 36 meses após a cirurgia.
\end{abstract}

received

December 5, 2016

accepted

March 27, 2017
DOI https://doi.org/

$10.1055 / \mathrm{s}-0037-1604057$.

ISSN 0100-7203.
Copyright (e 2017 by Thieme Revinter

Publicações Ltda, Rio de Janeiro, Brazil
License terms

(c) (i) $\ominus$ (\$) 


\section{Palavras-chave \\ - benigno \\ - cotiledonoide \\ - leiomioma \\ - simplástico}

Conclusão De aparência bruta e grosseira, os leiomiomas dissecantes na forma cotiledonoide têm natureza benigna. Até hoje, células atípicas não haviam sido relatadas nesse tipo de tumor. Apesar dos aspectos simplásticos, os leiomiomas dissecantes na forma cotiledonoide são entidades clínicas benignas. Cirurgiões e patologistas devem estar familiarizados com essa variante.

\section{Introduction}

Cotyledonoid dissecting leiomyomas are a rare variant of leiomyomas with a disparate gross appearance. They generally arise from the myometrium and extend to the broad ligaments. This particular type of tumor typically incorporates various characteristics, including dissecting growth and perinodular hydropic degeneration. ${ }^{1,2}$ Mitoses, coagulative necrosis and atypical cells have not been reported in this variant. We report a case of a cotyledonoid dissecting leiomyoma in a 38-year-old woman who presented with abdominal pain and underwent myomectomy.

\section{Case Presentation}

A 38-year-old multigravid woman presented with abdominal pain. An ultrasonography examination showed an irregularly contoured, subserous myoma with 95 mm x 93 mm dimensions arising from the uterine fundus. A cervicovaginal smear displaying normal cytology and endometrial sample demonstrating proliferative endometrium was obtained prior to the operation. A congested, multinodular mass was surgically resected by myomectomy, and the uterus was salvaged. Macroscopically, the mass was reddish brown colored and $135 \mathrm{~mm}$ x $105 \mathrm{~mm}$ x $90 \mathrm{~mm}$ in dimensions with a multinodular appearance (-Fig. 1). Closely packed, variable-sized nodules were resembling cotyledons. The cut surface was gray-white and congested in some areas. Microscopically, the tumor showed smooth muscle fascicles and micronodules (-Fig. 2A). Dilated and congested vessels were prominent at the peripheral areas of the nodules. Cellularity varied because of extensive hydropic degeneration (-Fig. 2B). Mononuclear and multinuclear atypical, bizarre cells were detected ( $\mathbf{- F i g . 2 C}$ ). Coagulative necrosis was not observed. There were 2 mitoses per 10 high power fields, and the immunohistochemical $\mathrm{K}_{\mathrm{i}}-67$ index of was $2-3 \%$ (-Fig. 2D). Intravascular involvement was not encountered.

The result of our macroscopic and microscopic examinations was 'cotyledonoid leiomyoma with the presence of symplastic (atypical) features'. The patient was followed up with regular postoperative visits in the gynecology outpatient clinic, and was alive and well 36 months after surgery, with no evidence of recurrence.

\section{Discussion}

Smooth muscle tumors are the most common neoplasms of the female genital tract, and they can demonstrate different growth patterns. ${ }^{1-4}$ Dissecting leiomyomas exhibit an unusual growth pattern, with apparent broad tongues infiltrating between myometrial muscle bundles. Cotyledonoid dissecting leiomyoma, or 'Sternberg tumor,' was first described in 1996 by Roth et al. ${ }^{2}$ Menolascino-Bratta et $\mathrm{al}^{5}$ coined the term 'angionodular dissecting leiomyoma'. These tumors have been described in women from the third to the early sixth decade of life. ${ }^{1}$ The common clinical findings are pelvic masses and abnormal uterine bleeding., ${ }^{3,6}$ These tumors can be large with an average dimension of $15 \mathrm{~cm}$ (range 4-41 cm). Three potential types have been described. The first type is the cotyledonoid dissecting leiomyoma (Sternberg tumor), which comprises an exophytic mass of multinodular tissue resembling the placenta, and is often protruding from the lateral surface of the uterine corn in continuation with the myometrium. The second type is the intramural dissecting tumor, which is confined to the uterus. These two types are histologically similar. The last type is pure cotyledonoid leiomyoma, which is not associated with either a parent intramural mass or intramural dissection. ${ }^{7}$

Cotyledonoid dissecting leiomyoma is characterized by disorganized smooth muscle fascicles with extensive hydropic degeneration and marked vascularity. ${ }^{1}$ Histological features suggestive of malignancy, such as cytological atypia, necrosis and increased mitotic activity, are absent. ${ }^{8}$

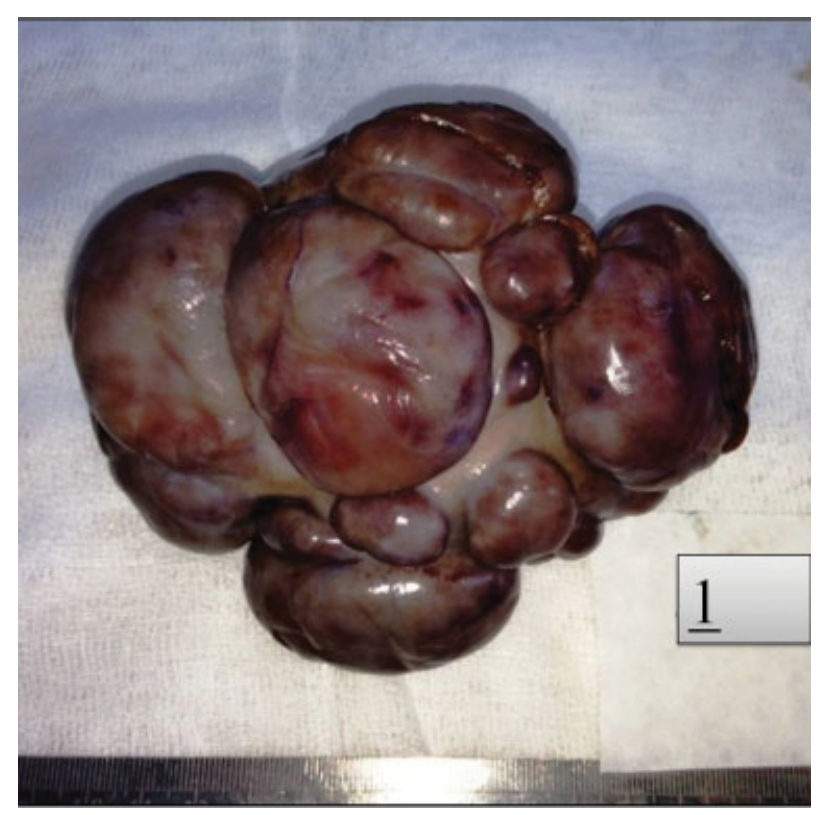

Fig. 1 Gross appearance of the lesion reminiscence of placental cotyledons. 


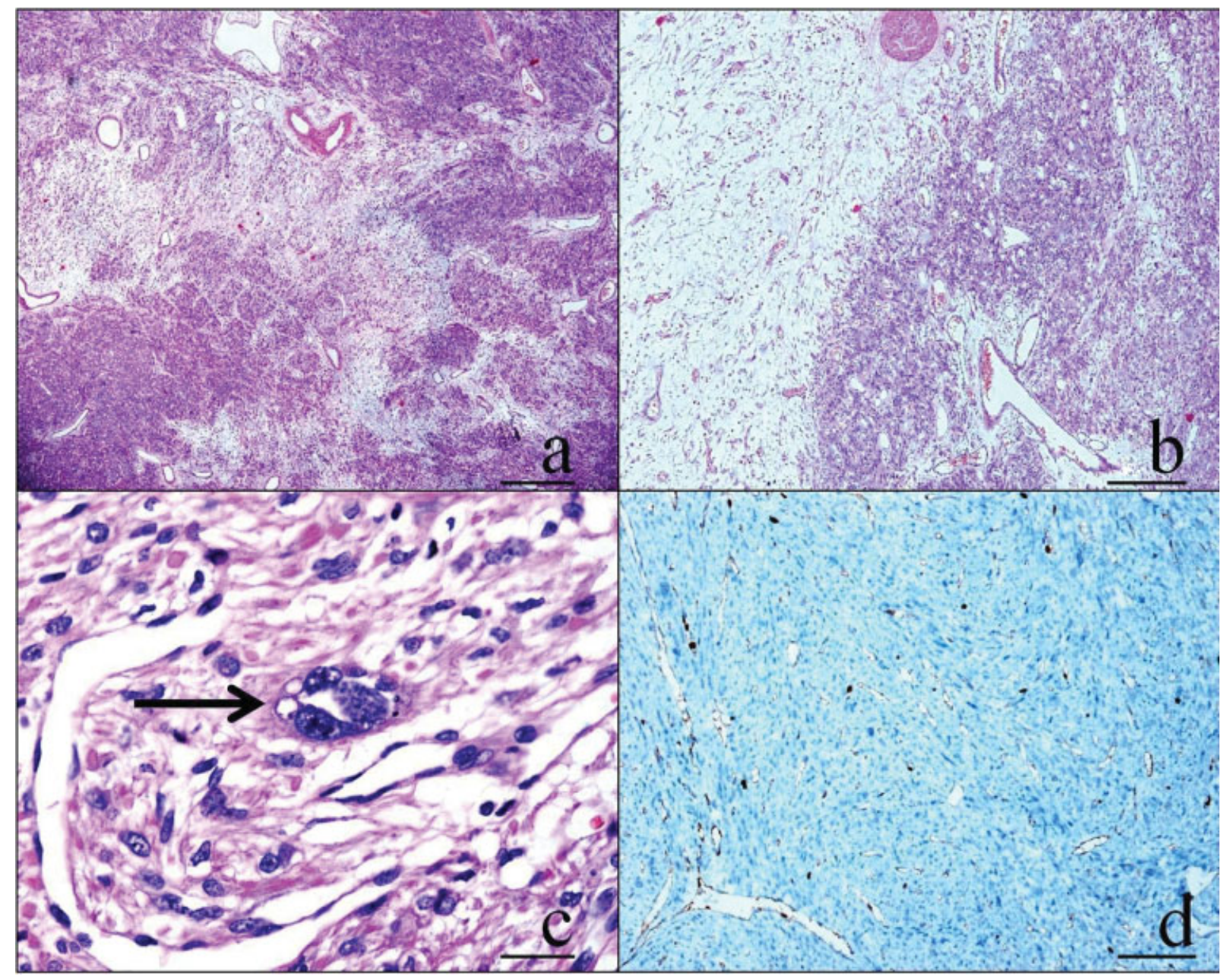

Fig. 2 (A) There are smooth muscle fascicles and nodules separated by vascularized and hydropic tissue (H\&E stain, $x$ 20). (B) Perinodular extensive hydropic degeneration is present (H\&E stain, $x 40)$. (C) There are mono and multinucleated atypical cells (H\&E stain, $x 400)$. (D) The immunohistochemical $\mathrm{K}_{\mathrm{i}}-67$ index is of $2-3 \%$.

The microscopic findings of our case were similar except for the atypical cells. Edema and congestion were prominent in some areas. Tumor cell necrosis, increased mitotic activity, and high immunohistochemical $\mathrm{K}_{\mathrm{i}}-67$ index were not detected, but a few mononuclear and multinuclear atypical, bizarre cells were observed, which makes our case unique. As an isolated finding, cytologic atypia, even when severe, is an unreliable criterion for the diagnosis of clinically malignant uterine smooth muscle tumor, as it may be observed in clinically benign neoplasms such as our case. These changes have been noted in leiomyomas excised from women taking progestin; however, there was no history of progestin use in our patient. A leiomyoma that exhibits moderate to severe cytologic atypia is designated as an atypical leiomyoma. By definition, mitotic figures cannot be present in numbers in excess of 10/10 high power fields. In atypical leiomyomas and tumor cells, necrosis must be absent. ${ }^{1}$

Intravenous leiomyomatosis, leiomyoma with perinodular hydropic degeneration, and myxoid leiomyosarcoma enter into the differential diagnosis. ${ }^{3}$ The tumor grows within the lumina in intravenous leiomyomatosis. Leio- myoma with perinodular hydropic changes does not have a gross appearance like placenta. ${ }^{4}$ Infiltrative growth pattern and high $\mathrm{K}_{\mathrm{i}}-67$ index are important to differentiate myxoid leiomyosarcoma from cotyledonoid dissecting leiomyoma. ${ }^{4}$ In our case, edematous areas resembled myxoid leiomyosarcoma, but were not infiltrative, and the $\mathrm{K}_{\mathrm{i}}-67$ index was of $2-3 \%$.

Atypical cells are not features of cotyledonoid dissecting leiomyomas. Both atypical (symplastic) and dissecting leiomyomas are benign. Despite the macroscopic and microscopic aggressive appearance, no example of malignant behavior or recurrence has been reported in a dissecting leiomyoma. ${ }^{3}$ So, it is important that surgeons and pathologists are aware of this rare, unusual entity to prevent misdiagnosis and overtreatment.

\section{Conflicts of Interest}

The authors report no conflicts of interest. The authors alone are responsible for the content and writing of the paper. 


\section{Acknowledgments}

The authors would like to thank Nurya Tatianya Buyuk Aleksanyan for the translation of the abstract.

\section{References}

1 Ersöz S, Turgutalp H, Mungan S, Güvendı G, Güven S. Cotyledonoid leiomyoma of uterus: a case report. Turk Patoloji Derg 2011;27 (03):257-260

2 Roth LM, Reed RJ, Sternberg WH. Cotyledonoid dissecting leiomyoma of the uterus. The Sternberg tumor. Am J Surg Pathol 1996;20(12):1455-1461

3 Kim MJ, Park YK, Cho JH. Cotyledonoid dissecting leiomyoma of the uterus: a case report and review of the literature. J Korean Med Sci 2002;17(06):840-844
4 Weissferdt A, Maheshwari MB, Downey GP, Rollason TP, Ganesan R. Cotyledonoid dissecting leiomyoma of the uterus: a case report. Diagn Pathol 2007;2:18

5 Menolascino-Bratta F, García de Barriola V, Naranjo de Gómez M, García Tamayo J, Suarez JA, Hernández Chacón AV. Cotyledonoid dissecting leiomyoma (Sternberg tumor): an unusual form of leiomyoma. Pathol Res Pract 1999;195(06):435-438, discussion 439

6 Smith CC, Gold MA, Wile G, Fadare O. Cotyledonoid dissecting leiomyoma of the uterus: a review of clinical, pathological, and radiological features. Int J Surg Pathol 2012;20(04):330-341

7 Fox H, Wells M. Haines \& Taylor Obstetrical and Gynaecological Pathology. 5th ed. London: Churchill Livingstone; 2003

8 Nucci MR, Oliva E. Gynecological Pathology: A Volume in the Series Foundations in Diagnostic Pathology. London: Churchill Livingston; 2009 